\title{
Identification of Areas Irrigated by Central Pivot in the State of Goiás, Brazil
}

\author{
Welvis Furtado da Silva ${ }^{1}$, Henrique Fonseca Elias de Oliveira ${ }^{1}$, Manoel Henrique Reis de Oliveira ${ }^{1}$, \\ Eloisa Aparecida da Silva Ávila ${ }^{1}$, Evaldo Alves dos Santos ${ }^{1}$, Rafael Matias da Silva ${ }^{1}$, \\ Rafaela Santos de Oliveira ${ }^{2}$, Antônio Evami Cavalcante Sousa ${ }^{1}$, Gustavo Henrique Mendes Brito ${ }^{2,3}$, \\ Leandro Spíndola Pereira ${ }^{4}$, Estevam Matheus $\operatorname{Costa}^{5} \&$ Matheus Vinicius Abadia Ventura ${ }^{5}$ \\ ${ }^{1}$ Postgraduate Program in Irrigation in the Cerrado, Goiano Federal Institute, Ceres, Brazil \\ ${ }^{2}$ School of Agronomy, Evangelical Faculty of Goianesia, Goianesia, Brazil \\ ${ }^{3}$ School of Agronomy, University Center of Anápolis-UniEVANGELICA, Anapolis, Brazil \\ ${ }^{4}$ School of Agronomy, Goiano Federal Institute, Rio Verde, Brazil \\ ${ }^{5}$ Postgraduate Program in Agrarian Sciences-Agronomy, Goiano Federal Institute, Rio Verde, Brazil \\ Correspondence: Henrique Fonseca Elias de Oliveira, Postgraduate Program in Irrigation in the Cerrado, Goiano \\ Federal Institute, Ceres, Brazil. Tel: 55-628-456-9339. E-mail: henrique.fonseca@ifgoiano.edu.br
}

Received: February 1, 2019

Accepted: May 10, 2019 Online Published: July 31, 2019

doi:10.5539/jas.v11n11p1

URL: https://doi.org/10.5539/jas.v11n11p1

\begin{abstract}
The state of Goiás, Brazil offers a territorial division with well-defined areas in terms of water capacity. The water found in these dividers is used in various agriculture segments. There were identified in the Hydrographic Basins in the State, areas irrigated by central pivots used in irrigated agriculture that is developing very fast and this can become a problem if a control is not done. This study aimed to collect data, identify and quantify the distribution of irrigation systems of the central pivot type licensed and operating in a spatial format in the Hydrographic Basins in the State of Goiás. It raised digital data and physical media in order to understand how these were able to characterize the research area. It analyzed the maps, existing in the database of the State through digital (SIEG-State System of Statistics and Geographic Information of Goiás). With the use of AutoCAD programs, version 2018, there was utilized the geographic information plataform QGIS 2.14.19 with GRASS 7.2.1 has organized thematic maps of hydrographs and pivots. This material provided the possibility of compiling the fundamental data to structure the information that supports the descriptive dynamics of the number of pivots even in separate basins. This information analyzed and compared to other publications about pivots in Goiás contributed to the formation and elaboration of a data model for the year 2017. In the State of Goiás, Brazil, there is a total of 3,223 central pivot type equipment in operation irrigating an area corresponding to 234,226.12 hectares.
\end{abstract}

Keywords: irrigated agriculture, pivots, watersheds, remote sensing

\section{Introduction}

The global concern about the conservation of natural resources can be seen as a precursor to environmental awareness. In this context, water, unlike other natural resources of the earth, which is primarily an environmental good, can become an economic good. Throughout the Brazilian territory, water resources are managed by hydrographic basins, either in water bodies owned by the Union or by the states (M. F. Porto \& R. L. L. Porto, 2008).

In Brazil accounts for only $18 \%$ of all cultivated areas, corresponding to about $42 \%$ of food production in agriculture (Christofidis, 2005). The regions with the largest extensions in hectares of irrigated area of the country are: Southeast $(2,709,342)$, South $(1,696,233)$, Central-west $(1,183,974)$, Northeast $(1,171,159)$, and North (194,002), according to a survey conducted by the National Water Agency (ANA, 2017). In the central-west region the central pivot is one of the most used irrigation systems, mainly for the cultivation of crops such as corn, soybean, industrial tomatoes and other crops in the Cerrado region (Landau et al., 2013). 
The climate of the central-west region is characterized by a dry period in months of winter (April-May to September-October), which causes the reservoirs to reach low levels (Caetano \& Casaroli, 2017). In recent years, the central pivot irrigation system has considerably expanded in the state of Goiás, which has an area of 340,166 $\mathrm{km} 2$, where about 1.2 million hectares have potential for irrigation (Sandri \& Cortez, 2009).

The central pivot irrigation system has provided a significant advance in irrigated agriculture. One of the factors that has contributed to such an expansion of the use of irrigation through the central pivot in the central-west region is the operational ease, related to the high adaptability to topography and the low demand for labor and different soil conditions and irrigation practice (Medeiros, 2005), operational facilities, and control of this system's irrigation blade, obtaining high efficiency of application and distribution of water that has competitive costs due to the lower use of labor, besides the possibility are also associated for such growth (Sandri \& Cortez, 2009).

Considering the increasing use of the centralized pivot irrigation system, the objective of this study was to collect data, identify and quantify the distribution of irrigation systems of central and linear pivot irrigation systems, licensed and in operation, in a spatial format in the Hydrographic Basins in the State of Goiás in the Central-West region of Brazil.

\section{Method}

The study area corresponds to the State of Goiás, which has an area of $340,111,783 \mathrm{~km}^{2}$. The programs AutoCAD 2018 and QGIS 2.14.19 with GRASS 7.2.1 (previously known as "Quantum GIS") were used for the georeferencing system (GIS), providing visualization, editing and analysis of data in the Geographic Information System of open source and licensed under the GNU General Public License.

This work was done by searching for information provided by the State System of Statistics and Geographical Information (SIEG), in the form of Esri Shapefile that has a file format containing geospatial information in vector of ESRI (Environmental Systems Research Institute) producer of ArcGIS software. ESRI also developed and regulated as an open specification for data interoperability the information that referred to the irrigation systems of the state of Goiás that underwent the administrative process of environmental licensing with the aforementioned agency.

Geographic information, municipalities and hydrographic networks of the main basins were inserted based on the coordinates obtained in the spreadsheets and sequence introduced in the ArcGIS program. Subsequently, the visual classification of the irrigated areas by central pivot of the State of Goiás was carried out in the following basins: Rio São Francisco, Rio Javaés (Rio minor branch of Araguaia), Paraná River, Rio Tocantins upstream of Foz Araguaia River, Araguaia River upstream of Foz Rio das Mortes.

In the database, it was made the quantification of irrigated area of each basin and the count of the number of pivots in each municipality. A new map was then used, using the boundary vector of the sub-basin, resulting in the identification and quantification of the central pivots in the sub-basins of the state, accompanied by the respective database.

Maps with corresponding scales were generated, the polygons being digitalized to each area occupied by central pivot in the State and in each hydrographic basin. After the generation of the Portable Document Format (PDF) file, the area occupied by each central pivot was calculated through the Excel spreadsheet program in the elaboration of these maps for the following river basins: Araguaia River 1:3,000,000 km; Rio Tocantins 1:3,000,000 km; Paraná River 1:4,000,000 km; Rio Javaés 1:1,000,000 km and Rio São Francisco 1:600.00 km.

\section{Results}

Table 1. Total area irrigated by pivot irrigation systems with their total in each river basin of the state of Goiás, Brazil

\begin{tabular}{|c|c|c|}
\hline Watersheds & Pivots by Basin & $\begin{array}{l}\text { Areas irrigated by } \\
\text { Equipment (ha) }\end{array}$ \\
\hline São Francisco River (Rio São Francisco) & 135 & $10,406.65$ \\
\hline River Javaés (minor arm river of Araguaia) (Rio Javaés) & 0 & 0 \\
\hline Parana River (Rio Paraná) & 2,320 & $162,192.74$ \\
\hline River Tocantins upstream of mouth River Araguaia (Rio Tocantins a montante da Foz Rio Araguaia) & 502 & $33,917.67$ \\
\hline River Araguaia upstream from mouth River of Deaths (Rio Araguaia a montante da Foz Rio das Mortes) & 266 & $27,749.06$ \\
\hline Total & 3,223 & $234,266.12$ \\
\hline
\end{tabular}

Source: SIEG (2017). 


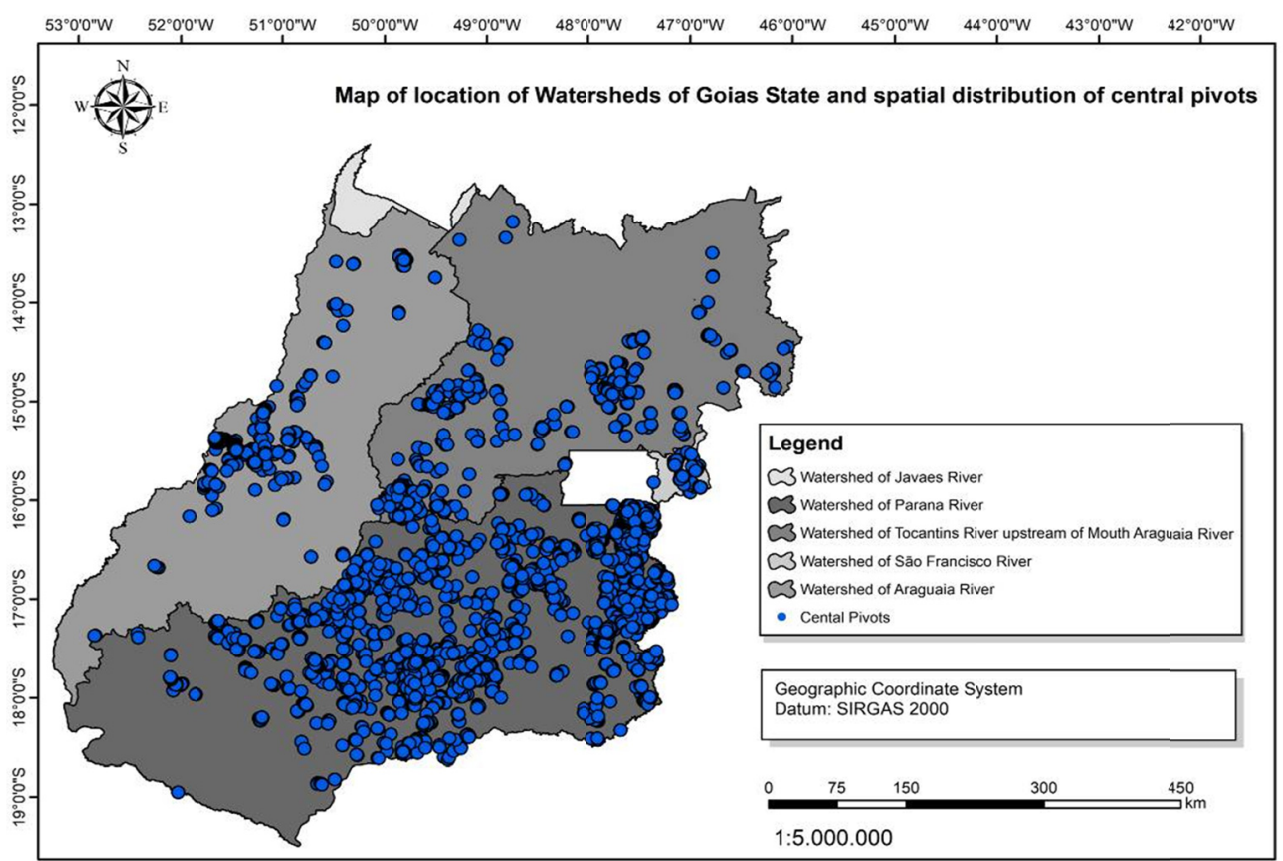

Figure 1. Geographical representation of the pivots in the watersheds in the State of Goiás, Brazil Source: SIEG (2017), modified by the authors.
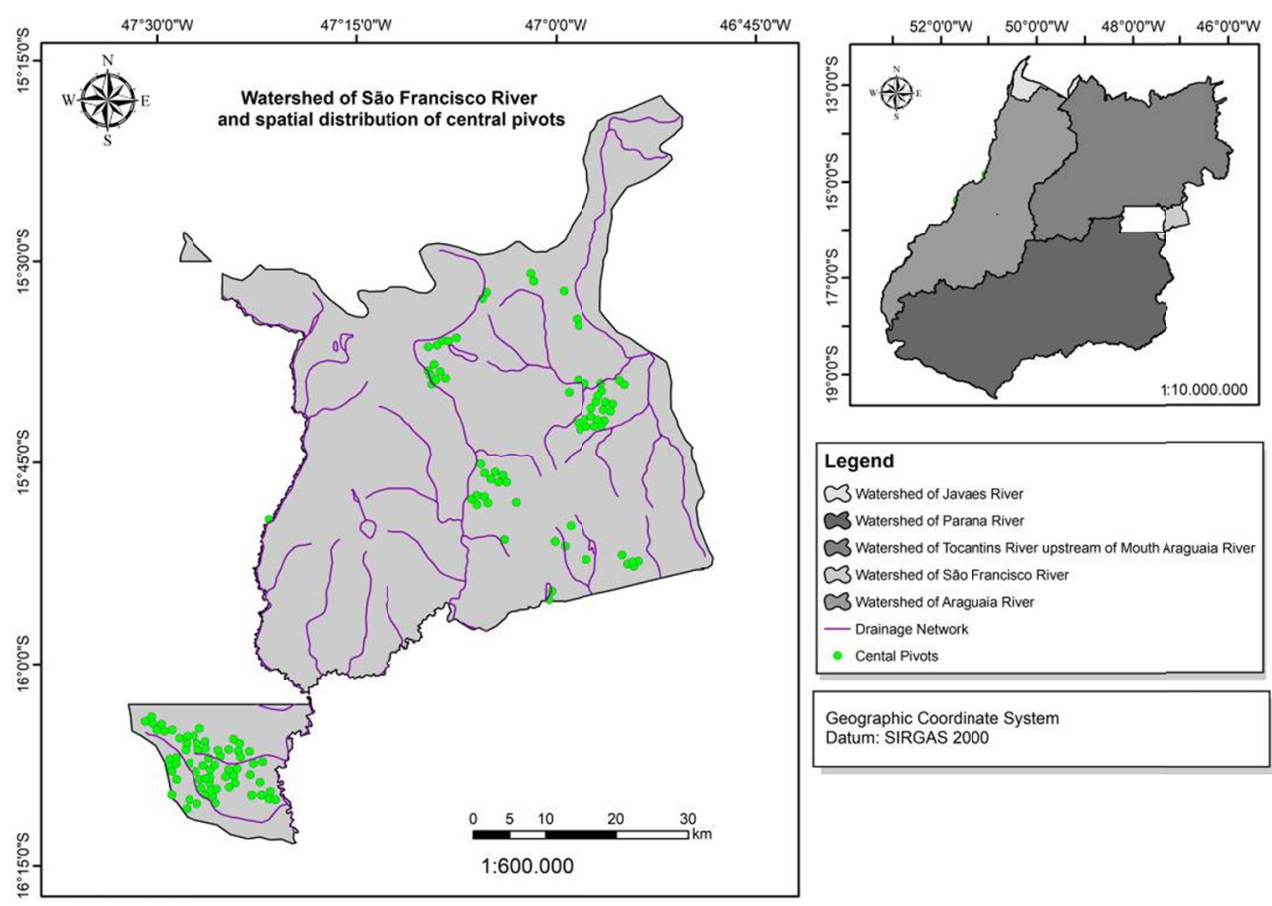

Figure 2. Map of the São Francisco river basin with its central pivot irrigation systems Source: SIEG (2017), modified by the authors. 

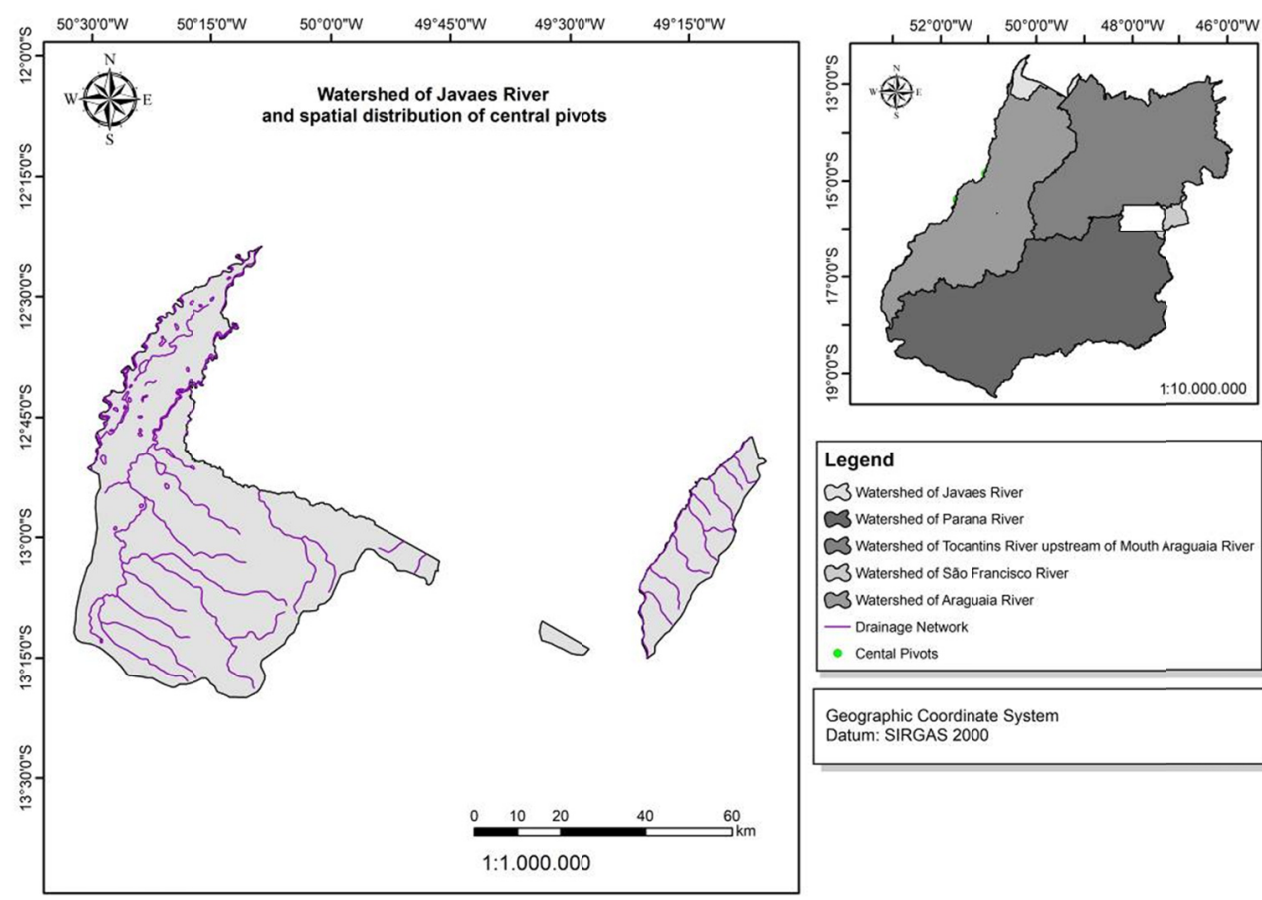

Legend

C3 Watershed of Javaes River

C. Watershed of Parana River

W Watershed of Tocantins River upstream of Mouth Araguaia River

3 Watershed of São Francisco River

4 Watershed of Araguaia River

— Drainage Network

- Cental Pivots

Geographic Coordinate System

Datum: SIRGAS 2000

Figure 3. Map of the river basin of the Javaes river with its central pivot irrigation systems Source: SIEG (2017), modified by the authors.

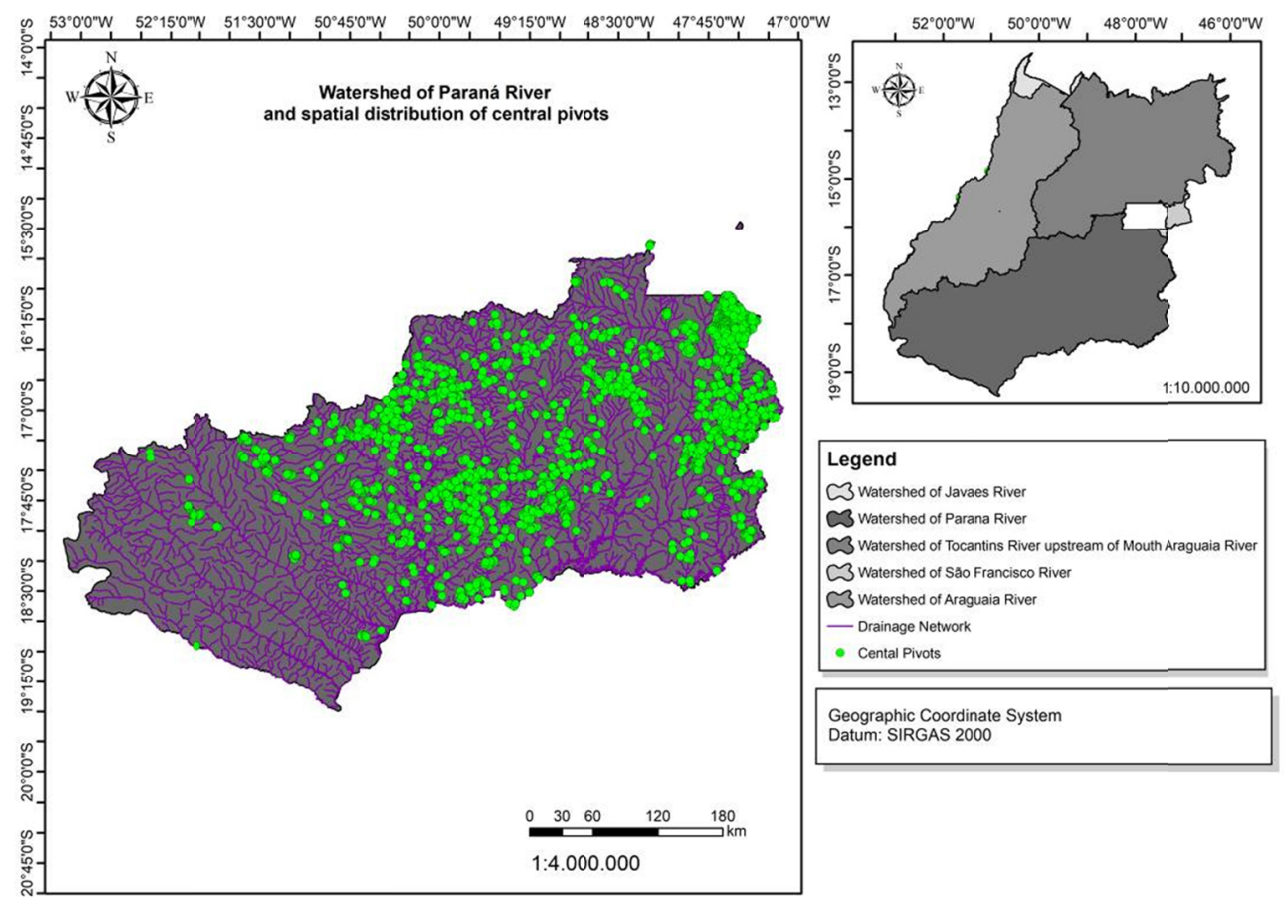

Figure 4. Map of the Paraná river basin with its central pivot irrigation systems

Source: SIEG (2017), modified by the authors. 

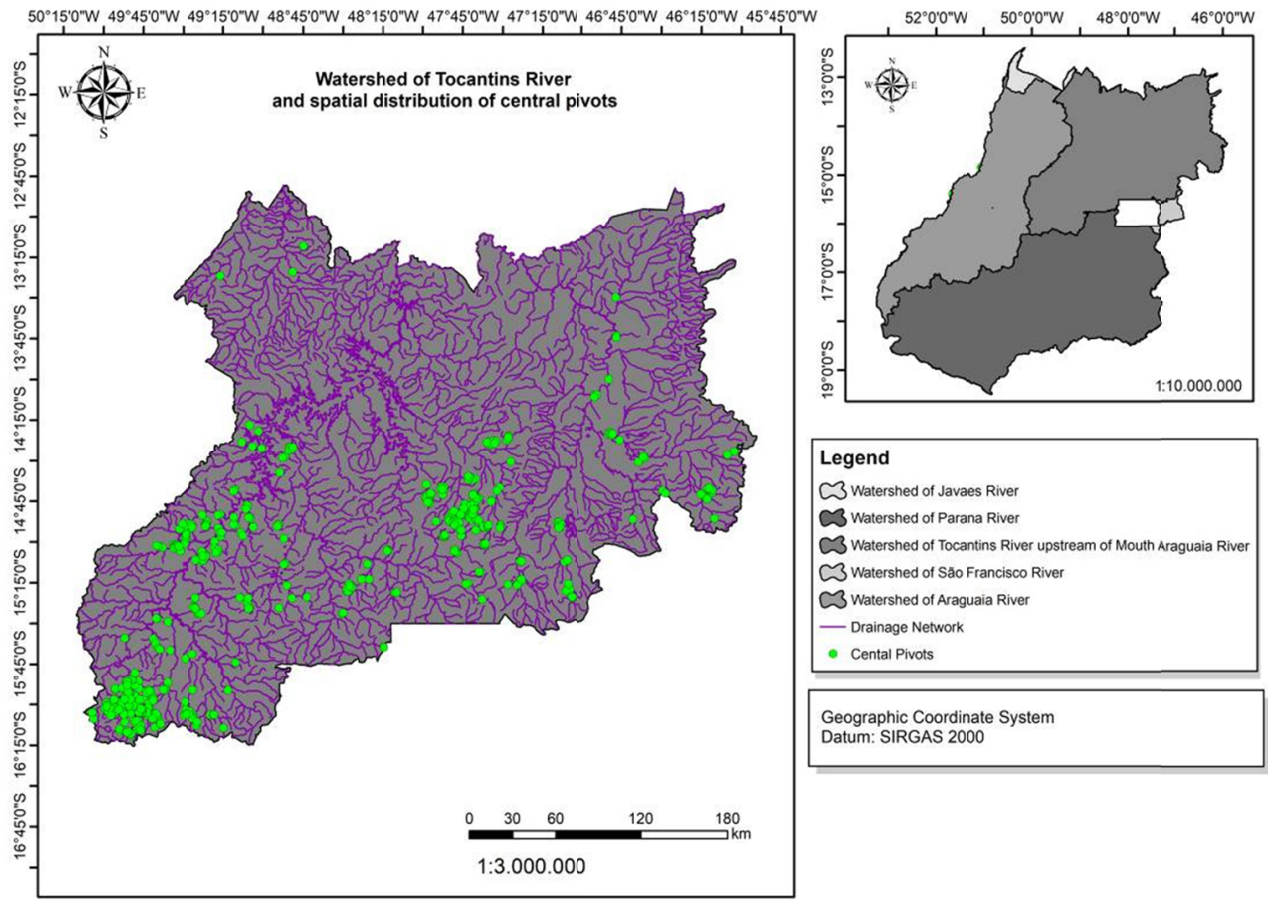

\section{Legend}

$\checkmark 3$ Watershed of Javaes River

C3 Watershed of Parana River

$\checkmark 3$ Watershed of Tocantins River upstream of Mouth Araguaia River

W3 Watershed of São Francisco River

$\widetilde{W}$ Watershed of Araguaia River

- Drainage Network

- Cental Pivots

Geographic Coordinate System

Datum: SIRGAS 2000

Figure 5. Map of the Tocantins river basin with its locations of central pivot irrigation systems

Source: SIEG (2017), modified by the authors.

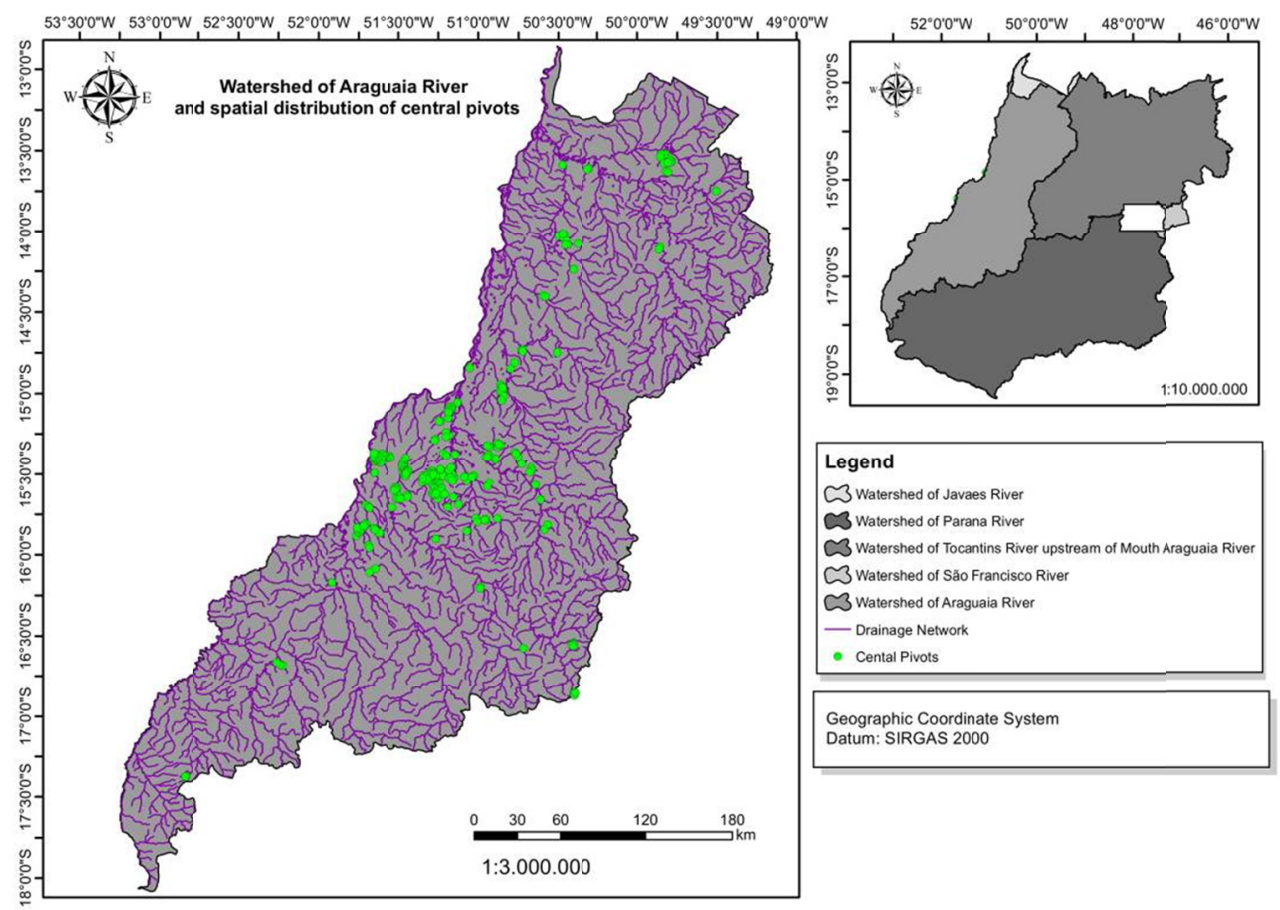

Figure 6. Map of the Araguaia river basin with its central pivot irrigation systems

Source: SIEG (2017), modified by the author

\section{Discussion}

The identification and description of the areas irrigated by the central pivot systems located in each river basin in the State of Goiás, quantifying and measuring the equipment and areas irrigated is presented in the Table 1. These areas are irrigated by a total of 3,223 units of equipment that are distributed in the areas of each basin, 
covering a total of 234,266.12 irrigated hectares. The geographic representation of the pivots in the watersheds in the State of Goiás is showed in Figure 1.

It is observed that the State of Goiás presented a growth in the areas irrigated by these equipments (Table 1), when compared to the results observed by Landau et al. (2010), which estimated a total of 187,037.00 ha irrigated by central pivot equipment in the State of Goiás in 2010.

It is verified, through a comparative analysis between the results presented in this study in 2017, and those obtained by Landau et al. (2010), that the number of irrigated areas by central pivot type systems, in the state of Goiás, showed an increase of $20.16 \%$ in irrigated areas during the last seven years. The number of equipment presented in Table 1 showed an increase of $24.38 \%$, which shows the increasing use of these equipments in the state, possibly associated with the financing programs that enable farmers to acquire them.

It is verified that the data published by Landau et al. (2010) show that in the 21 st century there was a $98.9 \%$ increase in irrigated areas in the State of Goiás, and that as a consequence, the State became a major Brazilian agribusiness, and has been maintaining since then among the first places in production and productivity.

In the comparison of the results of both studies, it can be observed that in the short period of time, the total number of irrigated areas in the State of Goiás in the year 2015 was 211,000 ha (Landau et al., 2010) of seven years, there was an increase of approximately $47,229.12$ ha irrigated by central pivot in the State of Goiás, considering only the equipment raised with the SGEI One of the factors that has contributed to this expansion is the adoption of strategies that aim to encourage the protection of permanent preservation areas (PPAs), and the maintenance of springs, helping to increase and improve the quality of the available water, and the use of this equipment in irrigation brings benefits to the agricultural production of the country., as well as the conscious use of resources, which will contribute to the improvement in the amount of water available, reflecting the permission of future expansion of irrigated areas in Brazil.

Figures 2, 3, 4 and 5 show the distribution of the central pivot equipment along the hydrographic basins of the São Francisco, Javaes, Paraná, Tocantins and Araguaia rivers, respectively.

It was also verified that there was a high concentration of central pivots in the São Francisco River Basin (Figure 2) 135 central pivots equivalent to $4.44 \%$ of the total pivot equipment number, yet in the Javaés Basin (Figure 3) Araguaia), there were zero pivot units not quantifying irrigated area in the Paraná River Basin (Figure 4) (2320 central pivots equivalent to 69.23\%), in the Tocantins Basin upstream of Foz Rio Araguaia (Figure 5) (502 central pivots equivalent to 14.48\%) and in the Araguaia Basin upstream of the Rio das Mortes mouth (Figure 6). These equipments occupy a total area of 234,266.12 ha.

The most representative river basins were Paraná River with irrigated area of 162,192.74 ha), Tocantins River upstream of Foz River Araguaia irrigated area with 33,917.67 ha and Rio Javaés Basin Araguaia) because it did not contain pivot equipment, thus not quantifying irrigated area. It can be related to the fact that the number of equipments and areas irrigated by basin had a significant increase, but attention must be paid to growth in a sustainable and politically correct way, in which the number of grants must also be growing and following the law of waters Law No. 9,433, of January 8, 1997 (Brasil, 1997) and Law n 13,501 of October 30, 2017 (Brasil, 2017).

The number of equipment installed in the state is likely to continue to increase. The correct management of water use in watersheds in Goiás should be constantly updated, noting that, over the years, pivot irrigation technology will be easier to acquire and this will increase the number of rural users.

In Cristalina there was an increase of more than 8,000 hectares when compared to the studies of Landau et al. (2010), with those made by Barbalho and Miyashita (2017). Because it is the largest in irrigated area and consequently in number of pivots, going from 49,139 to 57,307 irrigated hectares and this area produces more than another 259,200 hectares not irrigated. Thus, it is possible to highlight the great potential of irrigation to increase productivity in plant production.

It can be emphasized and supported the considered increase in recent years, revitalize government programs for rural finance, and it is also observed that for the agricultural economy being one of the bases of the State of Goiás and of utmost importance that the government and the teaching and research entities seek the extension and dissemination of this data to encourage one of the driving wheels of our country.

In the State of Goiás, Brazil there is a total of 3,223 central pivot type equipment in operation irrigating an area corresponding to $234,226.12$ hectares. Irrigation via central pivots has a higher concentration in the Paraná River basin. 
Half of the State of Goiás, in the north and west, have few central pivotal type equipment, due to the characteristic of the region that has the lowest agricultural proportion, but a large proportion in agriculture.

\section{References}

ANA (Agência Nacional de Águas). (2017). Retrieved from www.arquivos.ana.gov.br/imprensa/publicacoes/ AtlasIrrigacao-UsodaAguanaAgriculturaIrrigada.pdf

Barbalho, M. G. S., \& Miyashita, P. M. (2018). Mapeamento de pivôs centrais dos Estados de Goiás e Distrito Federal em 2015. Retrieved from http://www.imb.go.gov.br/pub/informestecnicos/10Mapeamento\%20dos\% 20Piv\%C3\%B4s\%20Centrais\%20de\%202015-201706.pdf\#sthash.lX0Ua8Qt.dpuf

Brasil. (1997). Lei $n^{\circ} 9.433$, de 8 de janeiro de 1997. Retrieved from http://www.planalto.gov.br/ccivil_03/ leis/19433.htm

Brasil. (2017). Lei $n^{\circ} 13.501$, de 30 de outubro de 2017. Retrieved from http://www.planalto.gov.br/ccivil_03/ _Ato2015-2018/2017/Lei/L13501.htm

Caetano, J. M., \& Casaroli, D. (2017). Sugarcane yield estimation for climatic conditions in the state of Goiás. Rev. Ceres, 64(3), 298-306. https://doi.org/10.1590/0034-737x201764030011

Christofidis, D. (2005). Água na produção de alimentos: O papel da irrigação no alcance do desenvolvimento sustentável. Universidade de Brasilia, Brasilia.

Landau, E. C., Guimarães, D. P., \& Reis, R. J. (2010). Mapeamento das áreas irrigadas por pivôs centrais no Estado de Goiás-Brasil. Retrieved from https:/ainfo.cnptia.embrapa.br/digital/bitstream/item/94072/1/ Mapeamento-areas.pdf

Landau, E. C., Guimarães, D. P., \& Reis, R. J. (2013). Mapeamento das áreas irrigadas por pivôs centrais no Estados de Goiás-Brasil. Embrapa Milho e Sorgo-Artigo em Anais de Congresso (ALICE), Simpósio Brasileiro de Recursos Hídricos, 20, Bento Gonçalves, RS. Anais... Porto Alegre, RS: Associação Brasileira de Recursos Hídricos.

Medeiros, A. M. M. (2005). Potencial de economia de energia elétrica em sistemas de irrigação a pivô central com uso de inversor de frequência no estado de Goiás (Masters dissertation, Universidade Federal de Goiás, Goiânia).

Porto, M. F., \& Porto, R. L. L. (2008). Gestão de bacias hidrográficas. Estudos Avançados, 22(63), 43-60. https://doi.org/10.1590/S0103-40142008000200004

Sandri, D., \& Cortez, D. D. A. (2009). Parameters of performance of sixteen center-pivot irrigation equipments. Ciência e Agrotecnologia, 33(1), 271-278. https://doi.org/10.1590/S1413-70542009000100037

SIEG. (2017). Sistema Estadual de Geoinformação. Mapeamento das Áreas Irrigadas por Pivôs Centrais no Estado de Goiás. Retrieved from http://www.sieg.go.gov.br

\section{Copyrights}

Copyright for this article is retained by the author(s), with first publication rights granted to the journal.

This is an open-access article distributed under the terms and conditions of the Creative Commons Attribution license (http://creativecommons.org/licenses/by/4.0/). 